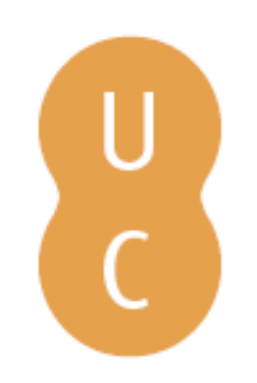

\title{
pompalina
}

\section{Historiografia e genealogia na cultura portuguesa anterior ao Conde D.Pedro de Barcelos}

\author{
Autor(es): $\quad$ Miranda, José Carlos Ribeiro \\ Publicado por: Imprensa da Universidade de Coimbra \\ URL \\ persistente: URI:http://hdl.handle.net/10316.2/31559 \\ DOI: $\quad$ DOI:http://dx.doi.org/10.14195/978-989-26-0405-3_4 \\ Accessed : $\quad$ 26-Apr-2023 15:41:03
}

A navegação consulta e descarregamento dos títulos inseridos nas Bibliotecas Digitais UC Digitalis, UC Pombalina e UC Impactum, pressupõem a aceitação plena e sem reservas dos Termos e Condições de Uso destas Bibliotecas Digitais, disponíveis em https://digitalis.uc.pt/pt-pt/termos.

Conforme exposto nos referidos Termos e Condições de Uso, o descarregamento de títulos de acesso restrito requer uma licença válida de autorização devendo o utilizador aceder ao(s) documento(s) a partir de um endereço de IP da instituição detentora da supramencionada licença.

Ao utilizador é apenas permitido o descarregamento para uso pessoal, pelo que o emprego do(s) título(s) descarregado(s) para outro fim, designadamente comercial, carece de autorização do respetivo autor ou editor da obra.

Na medida em que todas as obras da UC Digitalis se encontram protegidas pelo Código do Direito de Autor e Direitos Conexos e demais legislação aplicável, toda a cópia, parcial ou total, deste documento, nos casos em que é legalmente admitida, deverá conter ou fazer-se acompanhar por este aviso.

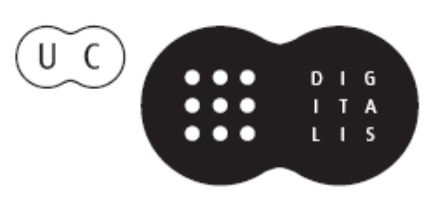


Maria do Rosário Ferreira

Coordenaçáo

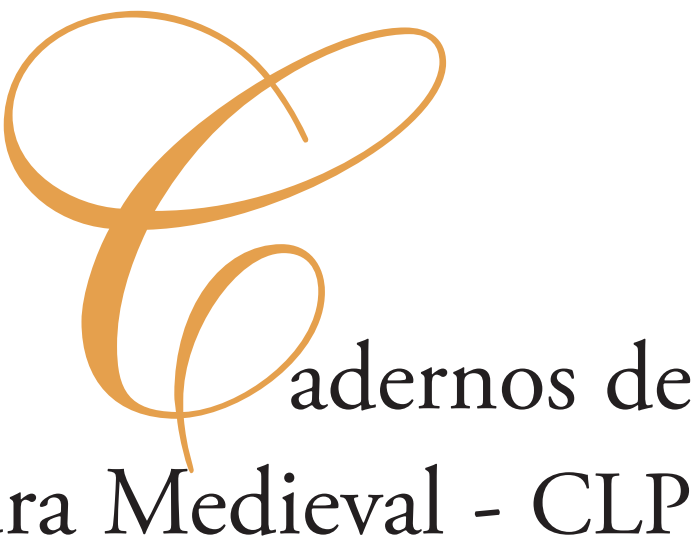

O Contexto Hispânico da Historiografia Portuguesa nos Séculos XIII e XIV

Em mémoria de Diego Catalán 
José Carlos Ribeiro Miranda

Professor da Faculdade de Letras da Universidade do Porto; investigador do Seminário

Medieval de Literatura, Pensamento e Sociedade (IF-FLUP/FCT).

\section{HISTORIOGRAFIA E GENEALOGIA NA CULTURA PORTUGUESA ANTERIOR AO CONDE D. PEDRO DE BARCELOS}

Da fundação do reino de Portugal, cujas etapas iniciais ocorrem ao longo do século XII, até à época em que D. Pedro, Conde de Barcelos, concretiza os seus vários projectos de escrita, escoa-se um longo período que não é comum ver tratado em conjunto no que diz respeito à produção de textos literários. Seja porque tal tarefa obriga a colocar lado a lado obras escritas em latim e em língua vulgar, que a prática universitária se obstinou em acantonar em disciplinas próprias e irremediavelmente opostas, seja porque os preciosismos exclusivistas na definição do que cabe ou não no conceito de «literatura» cavaram trincheiras inultrapassáveis entre textos que, sendo formalmente diversos, tratam frequentemente os mesmos temas; seja apenas porque a noção de História entendida como encadeamento temporal de acçôes humanas nas quais é possível destacar uma lógica interna atravessa entre nós um período de menor euforia, é difícil encontrar instrumentos que respondam a uma questão aparentemente simples, que é a de saber qual o sentido da produção literária em Portugal no período em apreço.

Não estando nos horizontes do presente trabalho suprir esta falha, que exigirá o concurso de esforços diversificados, também não cremos que ofereça qualquer utilidade considerar isoladamente algumas obras fora do respectivo contexto de escrita ou ignorar as linhas de força e as tradiçóes em que se inscrevem e que de alguma forma actualizam. Tal procedimento apenas pode resultar em abordagens parcelares, unicamente descritivas e historicamente limitadas e pobres. Avaliar a natureza social ou institucional da produção historiográfica e genealógica ao longo do período em questão não é tarefa que possa ser levada a cabo fora de uma compreensão do comportamento dos actores envolvidos e das conjunturas que se vão sucedendo num prazo necessariamente dilatado. Impóe-se assim um breve conjunto de consideraçóes que nos deverá fazer remontar 
ao Portugal do séc. XII e às etapas que marcaram a constituição da monarquia e do reino.

Conquanto o tema possua uma dimensão em que o mito e a tradição se arriscam a impedir definitivamente uma observação serena e distanciada dos acontecimentos históricos $^{1}$, parece ser hoje correntemente aceite que aqueles sucessos - a constituição do poder monárquico autónomo e a delimitação do reino enquanto entidade reconhecida interna e externamente - decorrem essencialmente da acção convergente de um ramo da família régia leonesa-castelhana e de um forte grupo de infançôes locais sem ligações directas às famílias condais dominantes no território, ou com laços frouxos de vinculação a essas famílias $^{2}$, que levaram a cabo algo que se configura como uma revolta autonomista coroada de inegável êxito ${ }^{3}$.

Ponderada a literatura que sobre o assunto foi sendo escrita, tanto em Portugal como no conjunto da Península Ibérica em épocas não muito posteriores àquelas em que esses acontecimentos têm lugar, verifica-se que a autonomia portuguesa se apoia em alguns argumentos dos quais o primeiro é inegavelmente a aceitação de Afonso Henriques como herdeiro de um poder político proveniente da rainha Teresa. Tal aceitação tem lugar não apenas no interior do espaço português mas sobretudo na coroa unificada leonesa-castelhana sob o comando de Afonso VII. A esse argumento virá juntar-se um outro, cuja repercussão será enorme na literatura a partir dos anos finais do séc. XII, que é o reconhecimento da acção militar de Afonso Henriques e dos seus apoiantes, da qual resulta a apropriação de territórios sob o domínio muçulmano só efemeramente detidos, em tempos próximos, pelas monarquias cristãs.

Entre estas conquistas há que destacar as de Santarém e de Lisboa, cuja importância se estriba no facto de concederem à jovem monarquia portuguesa direitos que, à luz dos consensos da época, esta não podia reclamar facilmente sobre outras partes do território português situadas mais a norte. Com efeito, a soberania decorrente da conquista ao muçulmano sobre as regióes de Portucale ou de Braga eram secularmente reclamadas pelos

1 Tanto pela informação exaustiva que reúne e pondera como pelas conclusôes a que chega, e sobretudo pelo método utilizado na abordagem das várias fontes, onde prevalece uma constante e inconformada questionação crítica, remetemos apenas para Mattoso (2006).

2 Mattoso (1982: 37-114).

${ }^{3}$ Embora o governo da Rainha D. Teresa possa revelar já características configuradoras de uma monarquia autónoma, sobretudo no contexto em que tal instituição se pode entender no séc. XII, reportamo-nos essencialmente à conjuntura social e institucional que possibilitou o acesso ao poder de Afonso Henriques após S. Mamede, tal como é interpretada por Mattoso (1985b), até à consolidaçấo desse poder que terá ocorrido nos cerca de dez anos seguintes, processo consumado na paz de Valdevez - ou Portela do Vez, segundo a Chronica Adefonsi Imperatoris, ed. Falque, Gil e Maya (1990: 188). 
reis astur-leoneses ${ }^{4}$, e permanecia ainda muito viva a memória das campanhas portuguesas de Fernando Magno incidindo sobre os territórios entre Douro e Mondego, tão numerosos eram os textos redigidos entre os séculos XI e XIV que comemoravam ou apenas recordavam tal empresa militar ${ }^{5}$.

Esta escolha de argumentos só se entende porque, na Espanha cristã ao longo do séc. XII, a aquisição de direitos políticos pela acção militar de conquista atinge um consenso muito elevado, sobrepondo-se a outras legitimidades que também afloravam, como a que associava o poder territorial à ideia de reposição do reino visigótico, forjada desde cedo pela coroa leonesa e objecto de apropriação castelhana a partir dos finais do séc. $\mathrm{XII}^{6}$, ou a que decorria de direitos imperiais reclamados por poderes extra-peninsulares, recorrente ao longo de séculos ${ }^{7}$. A conquista de territórios próprios, para mais de importância e prestígio incontornáveis, era algo que todos os grupos monárquicos ibéricos - ou senhoriais candidatos à condição monárquica - procuravam, e que rapidamente se transformavam em argumento para afirmação de uma legitimidade difícil de pôr em causa.

$\mathrm{Na}$ sua diversidade formal e na especificidade da sua circulação, os mecanismos da literatura tiveram um papel importante na divulgação destes sucessos militares, tornando-os conhecidos e presentes à consideração daqueles que se entendia serem os interlocutores prioritários. A literatura foi, como era frequente nas sociedades mediterrânicas desde a Antiguidade, uma arma política de peso. É assim que se compreende a redacção do poema sobre a conquista de Almeria, que acrescentava um importante título de conquista própria a um rei, Afonso VII, que pretendia transpor para a Península os ideais imperiais

${ }^{4}$ Mencionadas em ambas as versôes conhecidas da Crónica de Alfonso III, as conquistas em terras portuguesas de Afonso I das Astúrias passaram para toda a cronística posterior que teve este texto como fonte.

${ }^{5}$ Lembremos que é na narrativa destinada a celebrar a conquista de Coimbra por Fernando Magno contida no Codex Calixtinus (circa 1250) que pela primeira vez surge Santiago no campo de batalha, tema destinado a ter uma extensa fortuna ao longo dos séculos XII e XIII. Mesmo sofrendo a concorrência de uma mais incisiva intervenção do apóstolo guerreiro na batalha de Clavijo travada por Ramiro I, narrativa redigida em meios leoneses ainda no séc. XII, o relato da conquista de Coimbra transitará para a cronística ibérica posterior em latim e em vulgar. Cf. Falque (2002). Embora já não adornada com a intervenção do Apóstolo das Espanhas, a conquista de Coimbra será ainda lembrada num poema épico dos finais do séc. XIII de cuja circulação há vestígios em Portugal, como veremos adiante.

${ }^{6}$ Sobre o tema, ver Martin (1984); Bautista (2009); Le Morvan (2009).

${ }^{7}$ A este propósito, é importante chamar a atenção para a Historia de rebus Hispaniae, redigida por volta de 1243, onde o arcebispo Rodrigo de Toledo reserva um importante capítulo para a refutaçáo das reclamaçóes de soberania sobre a Espanha provenientes de além-Pirenéus, enumerando os vários condes e reis que adquiriram a terra peninsular por direito de conquista. Entre eles, conta-se Afonso Henriques com referência à suas vitórias: «Vlixbonam, Sanctam Hireneam, Elboram, Sintriam cepit Aldefonsus qui primus in Portugalia habuit regis nomen", ed. Fernández Valverde (1987: 129-130) Especificamente para o território português, é de ter em conta um interessante capítulo que Brandão (1632-2008: 145-146) reserva aos actos de soberania exercidos por um representante do império romano-germânico de visita a Portugal no tempo de D. Dinis. Sobre o tema, ver ainda Maravall (1995: 403-472). 
então em crescendo no centro europeu, expressos na sua Chronica Adefonsi Imperatoris; e é também nessa linha que se deve entender, provavelmente, a redacção da Historia Roderici e do Carmen campidoctoris, verdadeiros manifestos do direito de conquista, conquanto a empresa a que se referem, o reino de Valência, tenha abortado e não seja fácil apurar, de momento, com que objectivos tais obras foram redigidas ${ }^{8}$.

Em conformidade, também em Portugal começa por ser escrito um texto de evocação da conquista de Lisboa, sob a forma de carta de um cruzado, destinado a circular fora da Península mas que estudos recentes relacionam com iniciativas assumidas com o concurso da corte portuguesa ${ }^{9}$, ao qual se segue um outro, o Indiculum fundationis Monasterii Sancti Vicentii ${ }^{10}$, em que a conquista de Lisboa ocorre como pano de fundo para a construção de um espaço sagrado destinado a tornar-se emblemático. O louvor da conquista aprofunda-se e hiperboliza-se no De Expugnatione Scalabis ${ }^{11}$, com a convocação da retórica da legitimação divina da acção guerreira a que corresponde a utilização de um tipo de escrita tributária das narrativas dos textos sagrados ${ }^{12}$.

Embora o assunto careça de uma investigação aprofundada e actualizada, é sobretudo nos anos imediatamente posteriores à morte de Afonso Henriques que ganha forma a iniciativa de utilizar a escrita literária para a consolidação de um ideário político legitimador por parte dos meios governantes portugueses, do qual a redacção do De Expugnatione Scalabis pode ter já sido uma manifestação. Todavia, esse projecto virá a conhecer a sua peça fundamental no Cronicon Lusitano, escrito compósito onde tradiçóes analísticas antigas (os Annales Portucalenses Veteres ${ }^{13}$ ) são prosseguidas por outras mais recentes (os Annales Domni Alfonsi Regis $\left.{ }^{14}\right)$, sendo essa base estrutural expandida com recurso a outras fontes cronísticas, como a Crónica Albeldense, ou a narrativas de origem não identificada, provenientes da transmissão oral ou da iniciativa de quem promoveu o texto ${ }^{15}$. A conquis-

\footnotetext{
${ }^{8}$ A Historia Roderici foi datada por Menéndez Pidal (1969, II: 917) e Catalán (2000: 277-280) dos inícios do séc. XII, mas ultimamente têm surgido propostas de uma datação mais tardia, apontando para a segunda metade ou mesmo para a última década desse século. Cf. Martin (1992: 35-36); Montaner (2009).

9 Ver a argumentação aduzida por Branco (2001).

${ }^{10}$ Brandão (1632-2008: 291-294).

${ }^{11}$ Brandão (1632-2008: 289-191).

12 Cf. Guincho (2001).

13 Cf. David (1947: 257-340).

${ }^{14}$ Cf. Blöcker-Walter (1966: 151-161).

${ }^{15}$ A selecção de fontes diversas e respectiva conformação num relato organizado são procedimentos que normalmente se associam ao trabalho cronístico e não à mera anotação analística. Assim, o Cronicon Lusitano (também chamado Chronica Gottorum) será já uma proto-crónica ou mesmo uma recolha ordenada de materiais que permitiriam redigir uma crónica. Náo é normalmente tido em conta que este texto circulou pela Península na forma atrás descrita, tendo sido conhecido e aproveitado pelo scriptorium alfonsino no seu vasto
} 
ta territorial é aqui uma constante, embora ocorra associada a outros temas legitimatórios, como o auxílio divino ou a reclamação da herança dinástica que remonta a Afonso VI, o conquistador de Toledo, e à rainha Dona Teresa. Este último aspecto constitui um dos articuladores do discurso destes textos, revelando-se no facto de todos eles contabilizarem o reinado de Afonso Henriques a partir da vitória de S. Mamede ${ }^{16}$.

Este projecto de escrita é revelador de um poder régio que se constrói e se afirma no concerto ibérico e europeu, procurando, por isso, ajustar a sua imagem a uma pauta que seria reconhecível por parte dos seus possíveis interlocutores fora do reino. O uso do latim na construção de uma prosa que alinha os argumentos já mencionados, mesmo constituindo uma opção conservadora ${ }^{17}$, revelou-se ajustado aos propósitos enunciados. Não transparece em nenhum momento que os destinatários destes textos fossem internos, o que significa que os meios crúzios responsáveis por este projecto de escrita não sentiam que os actores sociais que haviam servido de suporte à constituição da monarquia se tivessem afastado do projecto. Ou seja, a acção guerreira e conquistadora de Afonso Henriques, prolongada em circunstâncias peníveis por Sancho I nos primeiros anos do seu governo,

trabalho compilatório de fontes historiográficas. Cf. Cintra (1950: CCLXXVII-CCLXXVIII); Catalán (1962: 69, 92); Fernández-Ordónez (1993: 251-253).

${ }^{16}$ Naquela que é uma das mais densas páginas até agora escritas sobre esta matéria, Cintra (1951: CCCXCII-CCCXIV e n. 214) via nas afinidades de escrita entre o De Expugnatione Scalabis, a Vita Theotoni e a Chronica Gottorum (Cronicon Lusitano) o sinal identificativo de uma mesma autoria, o que dava consistência à ideia de se estar perante um projecto concertado de escrita. Ultimamente, porém, foi proposta por Nascimento (1998: 222) uma dataçấo mais recuada para a Vita Theotoni, que exige a reponderaçấo da problemática textual desta obra. Se é verdade que a ausência de referência à canonização de S. Teotónio aponta para que a redacção primitiva do texto tenha ocorrido logo após a morte do prior crúzio em 1162, há contradiçōes insanáveis no seu interior que permanecem por explicar, nomeadamente a que diz respeito ao momento da atribuição da titulaçẫo régia a D. Afonso Henriques. Com efeito, ao longo de grande parte da obra não só essa titulação se dá por volta de 1140 (sem que haja, contudo, qualquer correlação explícita entre essa titulação e a batalha de Ourique), como são visíveis argumentos que inviabilizam a atribuiçấo do qualificativo régio a Afonso Henriques antes desse período. Todavia, na parte final da obra indica-se de um modo reiterado que Afonso Henriques reinava já desde S. Mamede, em sintonia com o que é dito tanto no Cronicon Lusitano como no De Expugnatione Scalabis. Tendo em conta este facto, bem assim como os argumentos já adiantados por Cintra, resta-nos pensar que o texto que contém a biografia de $S$. Teotónio conheceu uma reformulaçáo, cuja dimensão cumpre averiguar, no âmbito do projecto de escrita a que nos vimos referindo.

${ }^{17} \mathrm{Na}$ mesma época, o reino da Navarra, com o qual o reino de Portugal partilha uma similar posição de periferia relativamente aos reinos de Leấo e Castela (mesmo que esses reinos possuíssem, na altura, coroas distintas), faz opçôes totalmente diversas no tocante à mobilização da escrita como arma de afirmação legitimatória. Com feito, na redacção do Liber Regum ("Libro de los lignages de los reies», designação recentemente proposta por Georges Martin ao colóquio «Historiographie royale léonaise, castillane et navarraise du XIIe siècle. 2 Le Liber Regum, Paris, 2009»), obra escrita em meios afectos à corte de Sancho VI e destinada a dar consistência genealógica a uma casa régia que certamente sentia residir aí a sua maior debilidade, o latim é substituído pela língua vulgar e a prosa narrativa cede o passo à construção genealógica. Sobre esta obra, ver Catalán e Andrés (1970: LIII-LIV); Martin (1992: 27-33). 
constituía uma empresa suficientemente aglutinadora das forças sociais mais relevantes para retirar viabilidade ou utilidade a alguma forma específica de expressão aristocrática ${ }^{18}$.

\section{Os desalinhamentos aristocráticos}

Sabemos todavia que mesmo na fase inicial deste projecto político autonomista existiram focos de tensáo e fissuras no bloco dominante encabeçado por Afonso Henriques. Um desses momentos ocorreu após o desastre de Badajoz em 1169. Em circunstâncias que não é possível compreender em toda a sua dimensão, a assunção das responsabilidades de governo por parte do futuro rei Sancho foi acompanhada do exílio de algumas figuras de topo da aristocracia, como Pero Pais da Maia, alferes régio durante vinte e dois anos ${ }^{19}$, e até de membros da família real como Fernando Afonso, filho ilegítimo do rei, que mais tarde virá a ser Grão-Mestre da Ordem de S. João do Hospital ${ }^{20}$.

Singularmente, a primeira manifestação trovadoresca em galego-português terá origem num homem, João Soares de Paiva, que se contou entre esses exilados após Badajoz, conquanto a sua actividade poético-musical pouco tenha tido a ver com o que por então se ia passando no reino de Portugal. Na realidade, como procurámos mostrar noutro local ${ }^{21}$, o «Ora faz ost'o senhor de Navarra», único texto conhecido do primeiro dos trovadores que usaram o galego-português, compreende-se no contexto das movimentaçóes políticas de um grupo senhorial cujos interesses se fixavam no norte e centro peninsulares - os Cameros -,

${ }^{18}$ Uma vez mais, o recurso à comparação entre o que se passa em Portugal e noutros pontos da Península ajuda a interpretar tanto o que existe como o que está em falta. Por esta mesma altura, senão mesmo antes, circulavam na área castelhana tradiçôes épicas que seriam mais ou menos desenvolvidas, conforme a crítica que a elas se refere possua uma sensibilidade mais ou menos "tradicionalista", que davam conta de diferendos essencialmente relacionados com o poder e a terra. Como exemplo, veja-se o Poema de Mio Cid, cuja redacçáo conhecida data de 1207, onde o dissídio entre Afonso VI e o Cid, que é também a oposição entre duas camadas da aristocracia com implantaçôes territoriais diversas - cf. Catalán (2002: 11-31) -, terá como corolário a efémera conquista de Valência e uma actualizaçáo de toda a conflitualidade existente entre os vários reinos e domínios do Norte cristão. É ainda de ter em conta que um dos motivos mais fecundos dos cantares jogralescos, reflectindo, a nosso ver, as expectativas dos públicos que os escutavam e lhes pagavam, era a partição dos reinos por Fernando Magno, que uma vez mais se situava no âmbito do grande tema da instabilidade na definição da terra e do respectivo poder. Na realidade, a épica castelhana medieval foi-se nutrindo em grande medida da permanente inconformidade entre poderes e território, fazendo desta situaçáo histórica o eixo articulador de um género literário. Sobre a épica castelhana ver a poderosa síntese de Catalán (2000). Um confronto entre as tendências da literatura no ocidente e no centro da Península foi já por nós ensaiado em Miranda (1998).

19 Cf. Ventura (1992, II: 991)

20 Sobre a identificação desta personagem, ver Castro (1992). Este autor chama ainda a atenção para a documentação que mostra a associação de Teresa ao governo do reino ao lado do irmão, futuro Sancho I, nos anos que imediatamente se seguem ao desastre de Badajoz.

${ }^{21}$ Ver Miranda (2004: 15-77). 
bem à margem do reino de Portugal. Todavia, esse texto não mais é do que a ponta visível de uma actividade que representa um forte acto de afirmação de uma cultura aristocrática já bem enraizada na Europa de então, fundamentada em valores tipicamente feudo-vassálicos. O facto de os modelos literário-musicais que são próprios da poesia trovadoresca se terem difundido ao longo de cerca de uma geração em direcção aos círculos da nobreza situada mais a Ocidente, no reino de Leão e sobretudo na Galiza, significa que se haviam transformado num meio particularmente apto a exprimir a cultura aristocrática também nesta área geográfica da Península, vindo logicamente a suceder o mesmo em Portugal, sobretudo a partir do momento em que as circunstâncias o permitiram.

$\mathrm{Na}$ realidade, não é possível apurar qualquer presença da cultura trovadoresca em Portugal antes de 1217, ano em que Garcia Mendes de Eixo regressa do exílio em Leão a que o apoio às infantas irmás de Afonso II o havia levado anos antes. A partir de então, o fenómeno irá difundir-se rapidamente, poucas sendo as linhagens mais relevantes que não lhe ficaram de algum modo associadas ${ }^{22}$. Mas os Sousóes, a quem se deve a dianteira nesse domínio, reuniam um notável conjunto de condiçóes para assumirem a vanguarda da afirmação de uma cultura aristocrática em Portugal, já que, se no tempo dos primeiros reis portugueses se haviam revelado uma linhagem fielmente alinhada com a política régia, nos anos iniciais do reinado de Afonso II irão passar, eles também, para o campo da dissidência e do exílio. Possuíam importância social, força política e certamente capacidade militar. $\mathrm{O}$ afastamento relativamente aos territórios onde detinham honras e prerrogativas senhoriais, num contexto de incerteza e de crise prolongada, criou as condiçóes para que se dotassem de símbolos próprios de reconhecimento, entre os quais se conta o apoio directo à actividade trovadoresca ${ }^{23}$.

As modalidades do canto trovadoresco tiveram a particularidade de usar a língua vulgar contra o predomínio do latim nas formas textuais a que aludimos. Se exceptuarmos a precoce, mas efémera, utilização do galego-português em 1214 pelo rei Afonso II na

\footnotetext{
${ }^{22}$ Para a disseminação do fenómeno trovadoresco pelas cortes senhoriais do ocidente da Península Ibérica, veja-se Oliveira (1994: 303-440; 2001b). Ron Fernández (2005) alarga o quadro já definido, integrando nele figuras como Martin Sanches, filho de Sancho I e de Maria Aires de Fornelos, de quem era vassalo o importante trovador Joan Soares Somesso.

23 Na sua esclarecida introdução à genealogia dos Sousôes, Pizarro (1999, I: 209-210) chama a atenção para o facto de esta linhagem ter sido extremamente precoce na utilização de sinais heráldicos em Portugal, bem assim como no uso de um apelido estabilizado - de Sousa -, sendo ainda a única, até à segunda metade do séc. XIII, a quem era atribuída uma designação condal. Todos estes elementos revelam uma especial atenção ao domínio do simbólico como veículo de consagração do poder e do prestígio. A profunda adesão à cultura trovadoresca demonstrada por Garcia Mendes, no único texto que dele se conserva, vai rigorosamente na mesma direcção. Cf. Miranda (2004: 165-177).
} 
redacção do seu testamento elaborado nesse ano, num contexto marcado por uma crise política intensa ${ }^{24}$, esta língua tornar-se-á em Portugal, durante cerca de meio século, um património exclusivo da poesia trovadoresca, com a concomitante supremacia da cultura aristocrática daí decorrente. Mais ainda, as formas e modalidades desta cultura literária e musical vieram a revelar-se tão apropriadas à expressão aristocrática em Portugal que outras tipologias textuais de algum modo relacionadas com a cultura aristocrática, embora com diferentes temáticas e formulaçóes discursivas, acabaram por se diluir no seu seio, provocando em Portugal um panorama literário deveras unilateral mas em todo o caso perfeitamente compreensível à luz do que vimos afirmando ${ }^{25}$.

Ora a cultura trovadoresca, tal como se configurou em Portugal naquela que foi já uma «segunda geração de trovadores galego-portugueses» ${ }^{26}$, desconhece as noçóes de território e de tempo ${ }^{27}$. Traduzindo preocupaçóes e olhares voltados essencialmente para o funcionamento do grupo aristocrático donde emana, cultiva obsessivamente a temática do amor que se institui como simbolizador das tensóes tanto entre sexos como entre estratos e grupos. Tal facto é perfeitamente detectável quando a própria sublimação erótico-literária é ultrapassada, dando lugar a uma referencialidade mal contida que aflora em temas como a política matrimonial ou o rapto, tão típicos dessa fase do trovadorismo português. Isto significa que a percepção do mundo é interna ao grupo aristocrático e dependente essencialmente da regularidade do seu funcionamento. Tâo surpreendente autismo, apercebido pelos estudiosos como monotonia ou escassez de horizontes, apenas significa que essa cultura não faz eco de conflitualidades territoriais, nem sequer de ameaças provenientes de qualquer instituição régia que pusesse em causa a ordem aristocrática. As primeiras, como vimos, não existiam; e as segundas menos ainda, se for tido em conta que o acontecimento político central deste período - a deposição do rei Sancho II - é amplamente condicionado por um conflito cavado no seio da aristocracia que suportava o fenómeno trovadoresco ${ }^{28}$. O exclusivismo da expressão trovadoresca no panorama português deste período não traduz apenas a pujança da iniciativa aristocrática em Portugal, sendo revelador de algo mais extenso e profundo, que é a hegemonia política e social dessa mesma

${ }^{24}$ Cf. Mattoso (1985a).

${ }^{25}$ Sobre o assunto, ver Miranda (1988).

${ }^{26}$ Miranda e Oliveira (1995).

${ }^{27}$ Sobre esta temática, ver Oliveira (2001a).

${ }^{28}$ Como é sabido, os ecos trovadorescos dos acontecimentos portugueses que se desenrolam em torno da guerra civil de 1245 são provenientes do círculo de trovadores e jograis afectos ao príncipe Afonso, compreendendo-se no âmbito das iniciativas de apoio ao monarca português levadas a cabo pelo futuro rei-Sábio. Sobre o assunto, ver Santos (2009). 
aristocracia sobre o reino de Portugal que acompanha uma fase de intensa senhorialização e de simultâneo condicionamento da monarquia.

Se o poder sobre a terra não colocava desafios visíveis à aristocracia, também não era ainda chegado o tempo de abandonar o olhar sobre o momento presente e convocar as memórias criadoras de identidades e legitimadoras de prerrogativas. Esse olhar defensivo virá a justificar-se mais adiante, quando da corte régia surgirem amostras de incomodidade perante a extensão e intensidade do domínio aristocrático sobre o reino. Ora a historiografia é essencialmente memória, qualquer que seja a modalidade da organização discursiva que adopte. Assim, do lado aristocrático do reino de Portugal, o vazio historiográfico que a história veio a registar apenas significa que essa fase defensiva não chegara ainda e que não se justificava que os mecanismos que constroem as memórias fossem então activados no plano da escrita.

$\mathrm{Na}$ realidade, o que se torna surpreendente não é tanto a permanência da actividade trovadoresca em Portugal ao longo de um período táo extenso, mas o silêncio por parte de outras instâncias das quais poderiam provir testemunhos, de qualquer tipologia ou língua, do uso das potencialidades do investimento literário ${ }^{29}$. Entre os finais do séc. XII e a mencionada actividade dos anos finais do reinado de Afonso III, a corte régia portuguesa não parece ter-se interessado pela produçáo de textos de qualquer tipo, nomeadamente de propósitos historiográficos, os mais ajustados a acompanhar os processos de afirmação de um poder monárquico. Longo e surpreendente silêncio, intimamente ligado, a nosso ver, à fragilidade política vivida pelo poder régio português ao longo de todo esse período, que viu sucederem-se invasóes territoriais, um rei enfraquecido a quem sucede um filho ainda muito jovem, tudo entremeado por várias derrotas políticas e militares que vão levando a uma guerra civil endémica, culminando numa insólita deposição régia da qual emergirá um poder assente em compromissos necessariamente debilitantes ${ }^{30}$. Esta situação só virá a alterar-se na década de 1260, ou seja, já na parte final do reinado de Afonso III, altura a partir da qual os equilíbrios da escrita, acompanhando as redefiniçóes dos equilíbrios

${ }^{29}$ Ressalve-se a continuidade da produção literária proveniente de meios monásticos ou clericais que, todavia, parece manifestar um progressivo afastamento relativamente à política régia. Um exemplo desse facto é o Carmen Gosuini escrito para celebrar a conquista de Alcácer - cf. Herculano (1856: 102-104) - sobre cuja proveniência não foi até agora possível apurar nada de concreto. Sobre o assunto, ver Pereira (2000).

${ }^{30}$ Para os acontecimentos do tempo de Afonso II e de Sancho II, remetemos o nosso leitor para as biografias régias elaboradas por Vilar (2005) e Fernandes (2006). Sobre a recomposição do poder régio português nos anos imediatamente posteriores à crise de 1245, ver Ventura (1992, I: 275 e seg.). 
sociais e institucionais, não mais cessarão de se alterar velozmente, reformulando radicalmente o panorama até então conhecido neste domínio.

\section{«Crónica» e campo historiográfico em Portugal}

É frequente argumentar-se que a ausência no espaço português de verdadeiras manifestaçóes cronísticas até ao momento em que D. Pedro, Conde de Barcelos, concretiza o projecto da sua Crónica de Espanha constitui como que uma menoridade endémica, devida a uma dificilmente disfarçável menoridade cultural do reino ${ }^{31}$. A nosso ver, não iludindo as circunstâncias políticas que atrás referimos, em si explicativas de um défice de iniciativa literária por parte da corte régia portuguesa, torna-se difícil compreender como seria possível, no séc. XII ou no seguinte, meios portugueses produzirem algo semelhante a uma "crónica», se deste género tivermos como modelo a cronística leonesa e castelhana com a sua sucessão de dinastias que se estendem ao longo de um período temporal de vários séculos. Elaborar tal tipo de texto só poderia significar a assunção do passado histórico da monarquia leonesa e a sua continuidade, o que colidiria frontalmente com o princípio autonomista que presidiu à fundação do reino ocidental.

Em Portugal, a herança astur-leonesa sempre foi convenientemente secundarizada, o mesmo não se passando relativamente aos grandes monarcas castelhanos de ascendência navarra, Fernando Magno e Afonso VI. O primeiro soube tecer importantes alianças com os infanções portugueses, substituir a dinastia dominante em Leão e concretizar campanhas militares que levaram à conquista de parte importante do reino de Portugal; ao segundo, para além da manutenção de uma idêntica linha de apoio militar ao Ocidente, sobretudo no difícil contexto da invasão almorávida, ficar-se-á a dever a paternidade daquela que primeiro se havia de chamar «rainha» em Portugal. Além disso, embora em contextos diversos, ambos os monarcas terminaram os respectivos governos com a divisão dos reinos que lhes haviam pertencido, o que se tornava auspicioso para um território onde se iam definindo claras tendências autonomistas.

$\mathrm{Na}$ sua parte analística mais antiga, já o conteúdo do Cronicon Lusitano é revelador desta situação quando reduz os reis asturianos e leoneses a meros e descontínuos aponta-

\footnotetext{
${ }^{31}$ Cintra (1951: CDXII-CDXIII); Catalán (1962: 207-213).
} 
mentos que apenas são retidos porque de algum modo se relacionam com Portugal ${ }^{32}$, ao contrário do que sucede com Fernando Magno ou Afonso VI, sobre os quais se conservam narrativas mais desenvolvidas ou informaçóes de tal modo preciosas que virão a ser utilizadas pelos redactores da Estoria de España alfonsina, como vimos atrás. Ao proceder deste modo, institui-se no melhor testemunho das razóes que levaram a que a "cronística neo-isidoriana», a não ser no projecto assaz particular e extravagante de Pedro $\mathrm{Afonso}^{33}$, nunca viesse a ter qualquer réplica em Portugal, nem por parte dos meios interessados em construir uma imagem historiográfica da realeza, nem por aqueles que interpretavam a fundação do reino à luz de pressupostos aristocráticos, como veremos adiante.

De resto, a «crónica» régia ibérica medieval, conquanto nascida em Leão e tendo conhecido alguns prolongamentos e actualizações ao longo do séc. XII ${ }^{34}$, é essencialmente um produto dos grandes cronistas latinos da primeira metade do séc. XIII, a contas com uma realidade complexa que era a súbita expansão da monarquia castelhana-leonesa para sul, aumentando de uma forma notável o território sobre o qual esta exercia a soberania, mas incrementando também os problemas de gestão de uma tal diversidade de gentes, de línguas e de interesses ${ }^{35}$. Ora tais preocupaçôes são fundamentalmente alheias ao ambiente português, podendo mesmo, como pensamos que sucedeu ${ }^{36}$, gerar neste reino mais desconfiança do que aproximação, o que dificultaria a criação de condiçóes para que essa cronística, laudatória da expansão em nome da herança gótica, suscitasse algum tipo de interesse, muito menos ainda de apropriaçãa ${ }^{37}$.

Tal como já havia sucedido na produção historiográfica do reino de Portugal do séc. XII, quando, na segunda metade do séc. XIII, meios portugueses tomarem a iniciativa de redigir uma memória do reino em vulgar - a Primeira Crónica Portuguesa ${ }^{38}$-, fá-lo-ão

32 Para além destes apontamentos, há que chamar a atenção para as informaçôes contidas neste escrito relativas à acção dos infançốes portugueses no período posterior às invasóes de Almansor. Na esteira de David (1947: 334-335), já Mattoso (1982a) indicava a provável proveniência de Santo Tirso daquelas notícias que diziam respeito aos senhores da Maia, enquanto Krus (1998) situava no Mosteiro de Grijó aquelas que se referem a membros da família patronal deste cenóbio. A terem uma origem autónoma, constituirão sem dúvida a primeira manifestaçáo de uma escrita de raiz aristocrática no espaço que virá a ser Portugal.

33 Sobre o modo como a história ibérica, nomeadamente a problemática do goticismo, é encarada pelo conde D. Pedro de Barcelos, ver o artigo de Maria do Rosário Ferreira constante do presente volume.

${ }^{34}$ As duas crónicas latinas imediatamente posteriores ao reinado do conquistador de Toledo - a anónima Silense e a crónica compilada e prosseguida pelo bispo Pelaio de Oviedo -, serão actualizadas em ambiente castelhano, no final do séc. XII, na Crónica Najerense.

35 Sobre o sentido da cronística latina castelhana do séc. XIII, ver Martin (1992: 201-316).

${ }^{36}$ Cf. Miranda (2008).

37 Sobre o goticismo na cronística leonesa e castelhana, ver nota 6.

${ }^{38}$ Moreira (2008); Mattoso (2009a). 
acentuando ainda mais a descontinuidade face à herança castelhana-leonesa, ao concederem um papel quase fundacional a uma personagem oriunda de um espaço não-ibérico, o conde Henrique da Borgonha.

Deste modo, à inexistência de um espaço semântico-ideológico para a emergência de uma cronística «neo-isidoriana», tal como esta vem sendo definida, vem juntar-se, ao longo de parte importante do séc. XIII, uma acentuada fraqueza política dos meios régios portugueses. Estes dois factores concorrem para tornar inviável não apenas a concepção de um projecto cronístico promovido pela corte régia portuguesa, mas até mesmo qualquer processo de afirmação institucional por via da escrita.

\section{De um velho livro de linhagens}

Esta situação irá prolongar-se pelo menos até ao final da década de sessenta do século em questão, altura em que deverá ter sido redigida, em meios afectos à corte régia, a Primeira Crónica Portuguesa ${ }^{39}$. Como já afirmámos noutro local ${ }^{40}$, esse projecto cronístico deve ser lido à luz das ocorrências que então vão tendo lugar, nomeadamente as que traduzem a adopção de práticas reveladoras de uma maior consciência do exercício do poder da realeza, como a instituição do cargo de meirinho-mor ou a apropriação de legislação alfonsina propiciadora de uma prática da governação não apoiada na aristocracia ${ }^{41}$. Entre os vários conflitos abertos nesse período, interessa-nos particularmente aquele que leva Gil Martins de Riba de Vizela a abandonar o cargo de mordomo-mor que havia sido seu por cerca de onze anos, bem assim como as várias tenências que detinha no reino, para rumar a Castela, donde não virá a regressar, juntamente com o filho, Martim Gil. Com os Riba de Vizela afastam-se também de Portugal os senhores de Albuquerque e André Fernandes de Castro, sogro de Martim Gil, na sua efémera passagem pelo reino ${ }^{42}$,

\footnotetext{
39 A Primeira Crónica Portuguesa foi situada por Moreira (2008: 22) antes de 1282, altura em que é utilizada por Afonso X na composição da sua Versão Crítica da Estoria de España. Porém, a transcrição de vários passos constantes do fragmento do Liber Regum que acompanhava a crónica portuguesa já na versão inicial do projecto cronístico da Estoria de España (circa 1270) torna muito provável que essa crónica já existisse também pela mesma data. A este propósito ver Moreira (2009) e ainda as consideraçóes do mesmo autor no texto publicado no presente volume.

${ }^{40}$ Miranda (2009b).

${ }^{41}$ É por esta altura que se traduz o Fuero Real castelhano, onde é consagrada a capacidade legislativa independente do rei, naquele que pode ter sido o primeiro texto extenso e não documental redigido em português. A propósito, ver Ferreira (1987, I: 37).

42 Tenente de Riba Minho de 1256 a 1262, cf. Ventura (1992, II: 1006).
} 
desfazendo-se assim um dos pilares da aliança aristocrática em que Afonso III baseara o seu governo até então ${ }^{43}$.

Esta conjuntura reúne, a nosso ver, as condiçôes que propiciaram a redacção da Primeira Crónica Portuguesa, acto pelo qual a corte régia portuguesa punha fim a um silêncio de décadas. Na realidade, por muita que tenha sido a deferência para com a nobreza de infançóes revelada por esse texto cronístico - deferência magnificamente representada na figura de Soeiro Mendes que auxilia o jovem Afonso Henriques na decisiva batalha contra a mãe -, toda a sua trama narrativa acentua um perfil de independência da dinastia régia quer relativamente à sua ascendência enquanto ramo da dinastia castelhana-leonesa, quer face aos restantes grupos e instituiçôes que colaboraram na empresa política e guerreira de então. É à dinastia régia que a crónica atribui, por inteiro, a «conquista» do reino de Portugal.

Proferida num momento de acesa disputa como terá sido o vivido ao longo da década de sessenta, tal declaração pode bem ter levado os Riba de Vizela, a linhagem portuguesa mais ligada aos grupos aristocráticos castelhanos, a socorrer-se de meios argumentativos e representativos que a poesia trovadoresca não estava já em posição de oferecer. E assim, com toda a probabilidade, terá nascido o Livro Velho de Linhagens, marco de extrema importância na alteração do perfil da cultura aristocrática em Portugal e o segundo investimento historiográfico de algum vulto realizado em língua vulgar do Ocidente peninsular num relativamente curto espaço de tempo ${ }^{44}$. Na linha do que já sucedia com a pequena crónica régia, também aqui a aristocracia inaugurava o seu pronunciamento no capítulo da definição da terra que reclamava como sua e da legitimidade do seu comando, socorrendo-se para isso da sua representação da memória.

Aparentemente muito afastados na sua tipologia de escrita, o texto régio e o aristocrático terão tido todavia mais pontos de contacto do que é visível à primeira vista, já que ambos decorrem, embora de formas completamente distintas, do Liber Regum, compêndio genealógico composto na Navarra nos finais do séc. XII ${ }^{45}$ cuja fortuna em Portugal se veio a revelar surpreendente ${ }^{46}$. Na realidade, investigaçáo recente ${ }^{47}$ tem vindo a acumular argumentos no sentido de afirmar que a Primeira Crónica Portuguesa não começava, na sua forma originária, com a vinda de D. Henrique à Península, mas um pouco mais atrás,

43 Sobre o sentido dos acontecimentos vividos em Portugal nesta altura, veja-se a síntese de Mattoso (2009b).

${ }_{44}$ Para uma diferente contextualização da elaboração do Livro Velho de Linhagens, fundamentada numa cronologia um pouca mais adiantada, ver Krus (1994: 197-208).

45 Sobre o Liber Regum, ver a nota 17.

46 Para o Liber Regum em Portugal, consultar Cintra (1950a) e (1950b); Miranda (2010).

47 Ver Moreira (2008) e ainda o artigo do mesmo autor publicado no presente volume. 
com uma relato genealógico que sumariava a dinastia astur-leonesa desde a sua fundação com Pelaio até Afonso VI, o conquistador de Toledo, baseado no Liber Regum ${ }^{48}$. Porém a partir daí o texto evolui para uma escrita narrativa de pauta épica, embora devidamente entremeada com outras formas discursivas, em alguns casos analísticas ou enumerativas, num conjunto de natureza cronística. Ou seja, conquanto tendo como ponto de partida um texto genealógico, que lhe serve de introdução, depressa se afasta dessa modalidade de discurso para adoptar uma outra de maior eficácia perante uma potencial audiência colectiva, sobretudo quando associada ao uso da língua comum.

O Livro Velho de Linhagens adopta do Liber Regum a mesma estrutura organizativa, em que o sintagma genealógico predomina sobre as formas analísticas ou narrativas, utilizando em alguns pontos a mesma terminologia e expressôes expositivas muito idênticas ${ }^{49}$. Apesar disso, aproxima-se de novo da Primeira Crónica Portuguesa ao conceder um espaço quase autónomo à narração extensa, com a conhecida Lenda de Gaia, num trecho sem paralelo no livro navarro. Para a sua elaboração, cuja redacção primitiva terá ocorrido por volta de $1270^{50}$, o linhagista não contou apenas com informação genealógica proveniente do espaço português. Uma observação atenta revela que, para além do Liber Regum e de uma versão do * Conto de Salomão com base no qual concebeu a Lenda de Gaia ${ }^{51}$, se socorreu ainda de anais de matéria castelhana ${ }^{52}$ e de uma narrativa épica em língua vulgar, certamente versificada, na qual uma das personagens centrais era o rei Fernando Magno.

Isto significa que a preocupação do seu redactor não foi apenas documental, como muitas vezes se assume, mas que contemplou alguns investimentos numa mais cuidada representação do passado, o que se torna particularmente visível no prólogo e nas partes iniciais dos dois títulos que actualmente o compóem. Nada de surpreendente, tendo em conta que o prólogo enuncia os propósitos da obra e as referidas partes enumeram a fundação e a fase inicial das linhagens a que se referem, Sousa e Maia, onde se concentram informaçôes cruciais sobre a respectiva identidade histórica.

\footnotetext{
${ }^{48}$ Foi com esta forma que Cristóvão Rodrigues Acenheiro o conheceu no início do séc. XVI, levando Catalán (1962: 207-288) a identificá-lo como Crónica Portuguesa de Espanha e Portugal.

49 Sobre estes aspectos, ver Miranda (2009c).

50 A datação desta obra foi fixada por Veiga (1943), e posteriormente acolhida por Cintra (1951) e Catalán (1962) e (1970), a partir da cronologia das personagens mais recentes nela mencionadas. Embora uma datação ligeiramente menos recuada tenha sido proposta por Mattoso (1980b), e posteriormente aceite por Krus (1994), com fundamento em breves alusóes a eventos ocorridos depois de 1285, o mesmo autor Mattoso (1999) veio a considerar que o livro teria tido duas fases de redacção, sendo de conservar para a primeira, aquela sobre a qual incidem as nossas observaçóes, a dataçáo já anteriormente proposta.

${ }^{51}$ Miranda (1988); (Ferreira, 1998); Ramos (2004).

52 Miranda (no prelo).
} 
Todavia, considerada a natureza de cada uma, essas fontes tão díspares na tipologia um escrito genealógico em língua vulgar, uma relação analística em latim, e um animado conjunto narrativo de novo em vulgar - têm origem castelhana e contam-se entre aquelas que foram também usadas em textos marcantes da construção da identidade mítica daquele território ibérico. Na realidade, os Juízes de Castela, donde descendem quer os condes autonomistas, quer o Cid Rui Diaz, são peças centrais da construção do Liber Regum; os mencionados anais identificam os fundadores de Burgos e de Amaia; e o primeiro monarca castelhano, aquele que unificou Castela e o reino de Leão, do qual os condados do Ocidente eram parte integrante, é celebrado nos poemas épicos conhecidos e utilizados pela cronística alfonsina e pós-alfonsina aos quais o redactor do Livro Velho teve acesso.

A ponderação do uso destas fontes adquire particular significado se efectuada à luz das conhecidas alegaçóes do Prólogo segundo as quais a conquista do reino de Portugal ao mouro se ficara a dever à acção das cinco linhagens, omitindo-se totalmente qualquer referência ao concurso da monarquia portuguesa nesse processo. De facto, na sua perspectiva política e ideológica, a um evidente afastamento da nobreza portuguesa, em nome da qual falava, relativamente à dinastia reinante em Portugal devia corresponder uma deliberada e notória aproximação aos poderes que se haviam afirmado no centro da Península. Deste modo, o genealogista aumentava o raio territorial da acção das linhagens envolvidas bem para além dos limites do reino e adicionava-lhes o prestígio proveniente de alianças matrimoniais com poderosas dinastias régias ou grupos aristocráticos de toda a Península ${ }^{53}$.

Ainda assim, é necessário detectar diferentes estratégias seguidas no livro relativamente a cada uma das mais importantes linhagens nele consagradas. Enquanto para os da Maia, na condição de linhagem mais antiga, mas também já extinta por linha masculina, se procurava uma origem remota num rei Ramiro anterior à fundação de Leão ao qual a historiografia atribuía a vitória na batalha de Clavijo, complementando essa origem com sucessivas alianças matrimoniais asturianas e biscainhas, aos de Sousa, linhagem não só ainda activa, mas sem dúvida a mais importante do reino para além da linhagem régia, as preferências do genealogista iam, num período primordial, para alianças matrimoniais castelhanas, nas figuras de Don Diego, povoador de Burgos, e sobretudo de Fernando Magno, por meio de um seu hipotético filho bastardo, figura que, à falta de realidade histórica, teve uma fortuna importante nos mencionados poemas épicos.

\footnotetext{
${ }^{53}$ Miranda (2009c).
} 
Em ambos os casos, a busca de uma legitimidade que provém do centro da Península é evidente, com especial relevo para uma orientação que vai ao encontro da mitologia histórica castelhana. Em contraponto, as ligaçóes ao antigo mundo leonês são subtilmente desviadas ou até rasuradas ${ }^{54}$, o mesmo se passando no tocante à casa real portuguesa, sobre a qual se proferem palavras azedas ou se faz puro silêncio ${ }^{55}$.

\section{Uma Crónica de Castela traduzida}

Cerca de uma geração depois, numa iniciativa que tem tanto de pioneiro quanto de surpreendente, é traduzida para galego-português a Crónica de Castela. Esta crónica é uma peça especial no contexto da cronística em vulgar dos finais do séc. XIII. Considerada por Diego Catalán «la más interessada en el estamento nobiliario, la menos afín a la jerarquía eclesiástica y la menos dependente de la corona entre nuestras historias anteriores al siglo $\mathrm{XV}^{56}{ }^{\prime}$, arranca contudo do esforço alfonsino, ou seja, dos materiais reunidos no scriptorium de Afonso X tendo em vista a concretização da redacção da Estoria de España. Será pouco posterior à Versáo Amplificada escrita em 1289 na corte de Sancho IV e com esta versão partilha um ascendente comum, embora na parte referente à história mais recente, da morte de Afonso VI em diante, esse parentesco se transfira para a Versáo Crítica da Estória de España, a última das versôes eleboradas debaixo do controle directo do ReiSábio $^{57}$.

A Crónica de Castela é concebida, portanto, em meios situados perto da corte régia mas com uma enorme abertura ao mundo da nobreza. Na realidade, ao contrário do que sucedia com a cronística alfonsina, que combinava de uma forma equilibrada tradiçóes historiográficas leonesas e castelhanas, a Crónica de Castela oferece uma perspectiva castelhanizante da história peninsular. Um dos elementos centrais dessa perspectiva é o manifesto desinteresse

\footnotetext{
${ }^{54}$ Em Miranda (no prelo) procurámos mostrar que, na Lenda de Gaia, a estratégia de afastamento relativamente à dinastia leonesa consiste na oposição entre o filho primogénito de Ramiro I, Ordonho I, que se desprestigia por condenar à morte a própria mãe, e o filho mais novo do vencedor de Clavijo, Alboazar, que continua a linhagem do pai em Portugal. Esse mecanismo narrativo era de tal modo actuante à época que virá a ser recuperado e ampliado pelo Conde D. Pedro no seu Livro de Linhagens para servir de fundamento a uma versão totalmente inovadora da lenda dos Juízes de Castela. Sobre esta temática, ver Ferreira (2010).

55 Referimo-nos naturalmente ao conhecido apontamento narrativo transmitido pelo LV, ed. Mattoso e Piel (1980: 27-28,1M7), em que Afonso Henriques e D. Mendo, o Sousão, se afrontam com evidente desprestígio para o rei.

${ }^{56}$ Catalán (2002: 227).

57 Cf. Catalán (1962: 17-204); Campa (2000).
} 
pela dinastia leonesa, que em várias ocasiôes se dá por extinta, sucedendo precisamente o contrário com a ascendência que remonta de Fernando Magno aos condes de Castela e à realeza navarra. Essa ascendência condal castelhana é, todavia, transposta para a prosa cronística a partir do texto de um cantar épico a que já atrás aludimos, actualmente conhecido pela versão tardia designada Mocedades de Rodrigo, cujo início, centrado na lenda dos Juízes de Castela, segue as linhas genealógicas inauguradas pelo Liber Regum ${ }^{58}$.

Condes de Castela e linhagem de Rodrigo Diaz de Bivar formam assim as duas linhas genealógicas que vêm confluir na narrativa desta crónica castelhana. As suas primeiras páginas narram extensamente episódios onde sobressai o extraordinário par formado pelo rei Fernando e pelo jovem Rui Diaz, numa cavaleiresca disputa de funçóes entre o rei e o cavaleiro onde facilmente se reconhece o fundamental da pauta ideológica aristocrática nos finais do séc. XIII'

Tendo em atenção as alusôes à deposição de Sancho II que contém, a Crónica de Castela, no seu original, conhece ainda materiais provenientes de Portugal, provavelmente a Primeira Crónica Portuguesa que fora já usada por Afonso X na Versão Crítica da Estória de España ${ }^{60}$. Interessa ainda directamente ao reino do Ocidente da Península por outros motivos. Tanto a cronística anterior, latina ou vulgar, cujo texto retoma, como as Mocedades de Rodrigo, que lhe servem de fonte complementar para a parte inicial, são pródigas em afirmar que Fernando Magno é o conquistador de Coimbra e de todo o reino de Portugal situado entre o Douro e o Mondego ${ }^{61}$.

Todavia, as razóes que ditaram que uma crónica tão centrada na percepção castelhana da Península obtivesse o favor de uma tradução galego-portuguesa executada entre 1295 e 1312 não parecem ter sido apenas essas. A aclimatação da Crónica de Castela em ambiente galego-português só se compreende se tiver existido um núcleo aristocrático no Ocidente peninsular que perfilhava ideias legitimatórias semelhantes às que haviam já sido expressas anos atrás no Livro Velho de Linhagens, e ainda que esse grupo tenha tido uma convergên-

${ }^{58}$ É no início desta crónica que encontramos a versão mais radical da descontinuidade dinástica asturiana que conhecemos, cujo modelo é contudo o que se encontra já nas Mocedades de Rodrigo: «quando finou el rey dõ Pelayo, o Mótesińo, ficou o rreyno de Castela sen rey. Et fizerố y dous alcalles[...]» ed. Lorenzo (1975, I: 308). No entanto, segundo Martin (1992: 456), as Mocedades recolhem toda a matéria referente aos Juízes de Castela e sua posteridade, bem como as equívocas mençōes aos reis navarros («Sancho Abarca») não directamente do Liber Regum, mas sim do Poema de Fernán González.

59 Cf. Martin (1992: 503-519).

${ }^{60}$ Cf. Moreira (no prelo).

${ }^{61}$ Foi já avançada, por Montaner (1988), a ideia de que teria existido uma parte deste cantar épico, entretanto perdida, onde a campanha militar em «Portugal, essa tierra jensor» apresentava uma dimensão mais ampla do que o poema actualmente conhecido ou a crónica transmitem . 
cia com os meios aristocráticos castelhanos situados próximo da corte régia, responsáveis pela produção daquela crónica.

Elementos de recepção da Crónica de Castela: A2a e A2d

A tradução galego-portuguesa da Crónica de Castela existente (normalmente designada pela sigla $A 2^{62}$ ) foi ainda acompanhada por dois textos importantes para compreender o ambiente em que se veio a ancorar. Um deles destinou-se a fornecer a continuação a uma narrativa que terminava com a morte de Afonso IX e a unificação das coroas castelhana e leonesa em 1230 com Fernando III. Na realidade, em pouco mais de um fólio, esta versão conclui-se com uma breve súmula do restante período de governo de Fernando III, da totalidade do reinado de Afonso X e ainda de Sancho IV. Transitando de uma forma flagrante da ideologia legitimatória decorrente da própria crónica para as suas consequências políticas, esse breve texto, específico da tradução galego-portuguesa, mostra-se de grande dureza para com a política de Afonso X, sobretudo no tocante ao confronto com os nobres que marcou o final do reinado do rei Sábio e aos conflitos que ditaram a sua deposição de facto ${ }^{63}$ :

Et este rrey dom Afonso britou os foros aos poboos et deytoulles muytos peytos et muytos pedidos ena tera et bateu moedas de muytas guisas [...] Et o papa soube en verdade do arçobispo de Sanctiago don Gonçalvo Gomes et do Bispo dom Martiño de Leô em como desaforaua seus poboos et nố lle quiso dar o imperadgo [...] E depoys este rrey dom Afonso moueu-se para fazer hũ grande agrauamento a seus poboos, que quen ouuesse valia de dos marcos de prata que lle dese uno; et os poboos teueróse ende por muyto agrauados et alcarôse todos cono jnfante don Sancho, seu fillo, et guerrearó con el dous anos; et elle foy exardado dos rreynos estes dous anos, saluo Sevilla en que ficou com algũos poucos castelos ${ }^{64}$.

Seguindo uma lógica compreensível, dos meios da nobreza portuguesa que anos antes tinham revelado, no Livro Velho de Linhagens, uma manifesta hostilidade à monarquia que os governava intra-muros, emanava agora uma nova geraçâo que mantinha a mesma atitude, mas desta vez para com o monarca que, no reino unificado de Leão e Castela,

\footnotetext{
${ }^{62}$ Para o que se segue, ver Miranda (2008a).

63 Ver Alfonso (2002).

${ }^{64}$ A2d, ed. Lorenzo (1975: 899).
} 
mais se destacara na oposição às pretensôes senhoriais. Decididamente, a realeza, qualquer que ela fosse, desde que decidida a seguir uma política de supremacia face à aristocracia, era uma instituição com a qual estes meios conviviam mal...

A versão galego-portuguesa da Crónica de Castela presente em A teve ainda a precedê-la um texto que, apesar da sua reduzida dimensão e aparente irrelevância literária, se reveste de uma importância singular. $\mathrm{Na}$ realidade, tal como tivemos já oportunidade de defender, a Crónica de Castela, na sua origem, não se destinou a constituir uma parte de um todo, ao contrário do que a sua posterior utilização pelo Conde de Barcelos e pela Crónica de $1404^{65}$ pode dar a entender, visto que contém em si os elementos informativos suficientes para que não seja necessário explicar os seus antecedentes. Todavia, a ser-lhe aposta uma introdução, dificilmente esse texto poderia afastar-se muito da construção genealógico-legitimatória do Liber Regum, a única que veiculava uma alternativa consistente e castelhanizante à tradicional construção cronística leonesa.

É isso que vai suceder em A2 $\mathrm{a}^{66}$, tendo o redactor galego-português interpretado com uma extraordinária coerência os princípios em que se fundamentava a crónica que se propunha introduzir. E na realização deste propósito torna-se particularmente significativo que tanto as fontes a que vai recorrer como a fixação dos momentos e personagens que dão corpo a esse passado, onde o mito e a História se confundem, sejam em alguma medida os mesmos que haviam já sido seleccionados para compor partes nevrálgicas do Livro Velho de Linhagens. É necessário, todavia, ter em conta tanto as aproximaçóes como as diferenças entre estes dois textos, em ordem a avaliar o respectivo significado. Enquanto no Livro Velho de Linhagens (LV) apenas se detecta o conhecimento do Liber Regum (LR) em algumas referências e evocaçóes localizadas, em A2a este compêndio genealógico navarro é literalmente transcrito numa porção importante, desde a vinda dos Godos à Península até à ruptura dinástica do tempo de Afonso II.

Também o redactor de A2a, à semelhança do que ocorrera com o de LV, investiu fortemente na figura do rei Ramiro. Desta vez, porém, não se alude a esse Ramiro como cabeça de uma qualquer linhagem de infançôes, mas como o rei que protagonizou a ruptura com o poder muçulmano, recusando-se a pagar o tributo das cem donzelas. Num breve episódio, indica-se que, chamado à batalha em Clavijo, Ramiro vê a vitória sorrir-lhe pela

${ }^{65}$ Cf. Catalán (1995).

${ }^{66}$ O texto pode ler-se em Lorenzo (1975: 900-903). Para o que se segue remetemos o leitor para Miranda (2009a). 
aparição de Santiago em forma de cavaleiro branco, após o que retribuirá essa ajuda com a concessão dos famosos «votos»:

Apus este rreynou dom Rramiro que pobrou Leom et lidou cônos mouros daalé mar e daaquẽ mar por parias que os cristaos dauã aos mouros, $\mathrm{C}$ mjnjnas et uirgens, as $\mathrm{L}$ de nobles et as $\mathrm{L}$ de popullares. Ēna primeyra lide fforon vençudos os cristãos e acollerôse a huã mota. Et allj lles apareçeo o apostolo Ssantiago a el rrey e dissolles que en outro dia, como quer que fossen poucos, que lidassem cónos mouros et que el pareceria y muy fforte caualleyro et que u[ẽ]ceriā. Et en outro dia lidarố cố eles et matarô ende LXX uezes mjl et fforon os mouros v[ē]çudos et ffillarô os cristãos Callaforra. Entô derô os vodos a Ssantiago $[\ldots]^{67}$.

Neste ponto, torna-se também patente a utilização directa, embora de uma forma resumida, do texto do Privilegio de los votos a Santiago, enquanto no LV a dádiva do rei Ordonho a Santiago como retribuição dos favores recebidos - os «votos», afinal - se confinara a uma breve alusão, reveladora de um conhecimento indirecto de tal fonte ${ }^{68}$.

Embora LV e A2a sigam rumos divergentes na manipulação da figura do rei Ramiro, convergem em alguns pontos, dando a entender que há uma real proximidade entre estas duas iniciativas de escrita. A maior das convergências residirá mesmo na inserção de Ramiro I e do seu filho Ordonho num esquema sucessório herdado do Liber Regum que definitivamente não a comportaria, já que esta obra indica que a linhagem asturiana foi descontinuada a partir de Afonso II, o Casto. Essa singularidade não histórica tem sido vista como um inexplicável lapso ${ }^{69}$, e assim terá de ser interpretadea caso nâo se tenha em conta o que tal anomalia pode significar no contexto literário português. Num estudo recente $^{70}$, tivemos a oportunidade de defender a plena intencionalidade da inclusão de Ramiro I e do seu filho Ordonho neste texto como evocação da construção mítica realizada em torno destas personagens no Livro Velho de Linhagens.

A2a e o Livro Velho recorrem ainda a anais de matéria castelhana donde são provenientes as alusóes aos próceres D. Diego de Burgos e D. Rodrigo de Amaia (este apenas em A2a), e ainda algumas das acções protagonizadas quer por Ramiro, quer pelo seu filho Ordonho, nomeadamente o "povoamento» da «vila de Leom», que em A2a é atribuído ao primeiro.

\footnotetext{
${ }^{67}$ Lorenzo (1975: 902).

${ }^{68} \mathrm{LV}$, ed. Mattoso e Piel (1980: 50, 2A2).

${ }^{69}$ Cf. Cintra (1950b); Catalán (1962: 307).

${ }^{70}$ Miranda (no prelo).
} 
Por último, a gesta das Mocedades de Rodrigo, na versão conhecida no séc. XIII, é evocada tanto na parte final de A2a - o filho de Sancho Garcês é Sancho, de acordo com aquele poema, e não o Infante Garcia de que fala a historiografia ${ }^{71}$ - como no Livro Velho de Linhagens, quando menciona em lugar de destaque o filho de Fernando Magno, «par d'emperador». Esta pode constituir em absoluto a mais antiga menção conhecida quer ao epíteto do rei castelhano, quer à personagem do seu filho bastardo ${ }^{72}$.

É mais amplo o leque de fontes pertencentes ao «campo historiográfico» utilizado por A2a do que pelo Livro Velho de Linhagens. Contudo, a base estrutural é a mesma porque se trata das fontes sistematicamente utilizadas ao longo do séc. XIII para fazer e refazer o passado mítico castelhano. Que seja possível rastreá-las no Ocidente peninsular, sobretudo em Portugal, é bem revelador do perfil identitário daquela porção da nobreza galego-portuguesa onde esses textos circulavam e donde saíram as iniciativas linhagísticas e historiográficas a que nos vimos referindo ${ }^{73}$.

Uma nova iniciativa genealógica: o Livro do Deâo

A retoma da iniciativa genealógica sob a forma de um novo livro de linhagens não se fará sem que tenham decorrido algumas décadas mais ${ }^{74}$, com a redacção do chamado Livro do Deão. Trata-se do menos conhecido dos livros genealógicos medievais portugueses por aparentemente ser aquele que menor investimento faz em processos de construção simbólica,

71 Cf. Lorenzo (1975: 903).

72 «Dom Munio Fernandes de Touro filho de El Rey D. Fernando que foy par demperador». Seguimos aqui a lição do Ms. 47.XIII.10 da Biblioteca do Palácio da Ajuda, fol. 33r corrigindo pay em par.

${ }^{73}$ Embora não tenhamos elementos objectivos que apontem neste ou em qualquer outro sentido, tendo em conta as observaçóes que já fizemos em Miranda (2009a e no prelo), estes textos podem bem ter sido elaborados em meios afectos a Martin Gil de Riba de Vizela (ou «de Sousa»), segundo Conde de Barcelos, na derradeira fase da sua vida. Para além de esta personagem ter tido relaçóes familiares e políticas intensas com meios castelhanos, sendo em Castela que termina os seus dias, a utilização da figura do Rei Ramiro de Clavijo nesta obra, em consonância com o Livro Velho de Linhagens, pode bem funcionar como um sinal para-heráldico de identificaçáo do grupo familiar que, embora em geraçôes diferentes, patrocina ambos os textos.

${ }^{74}$ Certamente pela mesma época em que tem lugar a redacção da versão galego-portuguesa da Crónica de Castela, é traduzida também, desta vez a partir do árabe, a chamada Crónica do Mouro Rasis. Tal como se torna perceptível tanto pela tradição manuscrita da obra como pelas abundantes informaçôes indirectas conservadas que lhe dizem respeito, trata-se de uma iniciativa da corte de D. Dinis, por muito que na sua redacção tenha estado envolvido Gil Peres, o capelão de Per'Eanes de Portel. Não encontramos nessa obra o suporte para nenhuma construçáo do passado com um sentido semelhante ao das obras a que nos vimos a referir, e temos dificuldade em compreender o alcance e a configuração do projecto aristocrático dos Aboim-Portel que nela transpareceria, como pretende Rei (2005). Podendo ser lida como uma História da Espanha alternativa à versão leonesa, a sua tradução pode ter tido como propósito aumentar o caudal já iniciado pela Primeira Crónica Portuguesa, tal como foi sugerido por Moreira (2008: 95-97). Mas o tema é ainda demasiado incerto para que seja possível ir mais além. 
não faltando quem apenas veja nele um mero documento. Na realidade, lido o seu prólogo unilateralmente pode bem parecer que assim é, sobretudo porque são aí alegadas razôes de natureza eminentemente prática para a sua confecção ${ }^{75}$. Além disso, a expansão da matéria genealógica com grande generosidade, não se limitando a duas grandes linhagens e respectivas ramificaçôes e esquemas de aliança, também parece ir nesse sentido. Mas, vendo mais de perto, outras pistas de leitura podem facilmente ser encontradas, levando a pensar que se trata de um livro que de algum modo reage contra os vários implícitos daquele que fora patrocinado pelos Riba de Vizela algumas dezenas de anos antes.

O Livro do Deão é uma obra genealógica em que a primazia é toda ela concedida aos Sousóes que encabeçam a matéria com cinco títulos, alguns dos quais dedicados a linhas originariamente femininas, contra apenas dois títulos dos da Maia, sendo que um deles tem início com o dissídio interno pelo qual Soeiro Mendes da Maia não teria acolhido o irmão, Gonçalo Mendes, no couto de Santo Tirso ${ }^{76}$. A reposição de alguma matéria ausente do Livro Velho permite ao genealogista fazer o elemento de referência ${ }^{77}$ da linhagem dos de Sousa «consograr» com os da Maia na geração anterior à de Soeiro Mendes, conferindo-lhe assim uma maior antiguidade nos primórdios da fundação do reino. Por virtude da emergência do seu irmáo Gonçalo Mendes, Soeiro Mendes deixa também de ser o elemento de referência para os da Maia, recuando essa função para Gonçalo Trastamires da Maia.

Estas operaçóes são acompanhadas de outras que as complementam, como seja o desaparecimento da fase arcaica de ambas as linhagens. Todavia, no caso dos senhores da Maia, o que se omite é um prestigiante e fundacional passado, cujo sentido já atrás mencionámos; no caso dos de Sousa, essa omissão terá incidido tanto sobre as hipotéticas alianças matrimoniais castelhanas a que nos referimos, como sobre a não menos hipotética hostilidade para com Afonso Henriques e para com o avô deste, o conquistador de Toledo. O linhagista não quis atribuir a nenhuma linhagem portuguesa uma origem ou dependência que a remetesse para fora do espaço português sob a tutela benéfica de Afonso $\mathrm{VI}^{78}$, no tempo do qual, e sob o beneplácito do qual, se terá originado toda a nobreza portuguesa:

\footnotetext{
75 «[...] deste livro se pode seguir muita prol e arredar muito dano ca muitos vem de bom linhagem e non no sabem eles, nem no sabem os reis, nem no sabem os grandes homens [...]». Prólogo, $\$ \$ 1-2$, LD, ed. Mattoso e Piel (1980: 61).

${ }^{76}$ Cf. LD, ed. Mattoso e Piel (1980: 125, 7A1).

77 O elemento a partir do qual se dá a divisão da linhagem em ramos femininos e secundários para além do ramo principal. Cf. Miranda (2009c).

78 ... embora o casamento de Egas Gomes de Sousa com uma filha de Gonçalo Trastamires da Maia tenha levado a que a linhagem da Maia tivesse início com esta personagem, historicamente anterior ao governo de Afonso VI.
} 
[...] delo tempo del rei dom Afonso, o que ganhou Toledo, acá forom feitos os mais dos mosteiros e das igrejas e dos coutos e das honras. Ca em tempo deste rei que reinou longamente forom muitos ricos homens e infançôes que ora poremos por padroens onde descendem os filhos d'algo ${ }^{79}$.

Uma vez que é também em Afonso VI que tem origem a monarquia portuguesa e aqui o livro retoma um dos mais antigos dos critérios legitimatórios do reino no seu todo, como vimos no início do presente estudo ${ }^{80}$-, segue-se que nobreza e monarquia se encontram irmanadas numa unidade fundamental.

Mais do que contribuir para identificar o «deão» para quem o livro foi escrito certamente por volta de $1340^{81}$, resulta desta breve apreciação que o segundo dos livros genealógicos feitos em Portugal se afasta decisivamente dos princípios que subjazem à redacção das obras atrás mencionadas, revelando alheamento relativamente às tradiçôes da Maia e à sua orientação peninsular ao mesmo tempo que limpa as máculas castelhanas atribuídas no Livro Velho aos Sousa, cuja memória preserva com mais afinco. Assim, deve ter tido origem certamente em meios próximos da corte régia portuguesa, em todo o caso desligados da realidade ibérica.

É também sintomático que o Livro de Linhagens do Conde D. Pedro, redigido pouco depois com pleno conhecimento do Livro do Deão, vá retomar muitas das partes do Livro Velho que este havia abandonado, fazendo-o embora em obediência a lógicas completamente inovadoras e apenas compreensíveis no âmbito global do projecto de escrita do filho bastardo do rei D. Dinis.

\footnotetext{
${ }^{79}$ Prólogo do LD, ed. Mattoso e Piel (1980: 3).

80 «[Egas Moniz] fez senhor do reino o criado, a pesar da madre, a rainha dona Teresa, de cuja parte o reino vinha», LD, ed. Mattoso e Piel (1980: 131, 9A2).

${ }^{81}$ Cf. Veiga (1943); Mattoso e Piel (1980: 15-18).
} 


\section{Bibliografia:}

Alfonso, Isabel (2002). «Desheredamiento y desafuero, o la pretendida justificación de una revuelta nobiliaria». Cahiers de Linguistique et de Civilisation Hispanique Médiévale, 26, pp. 99-129.

Bautista, Francisco (2009). «Genealogía y leyenda». e-Spania, 7 [revista on-line]. URL: http://e-spania.revues. org/index18086.html. [Consultado a 20/11/2009].

Branco, Maria João (2001). «A Conquista de Lisboa na Estratégia de um Poder que se Consolida». In Nascimento (2001), pp. 9-51.

Brandão, Frei António (1632). Monarquia Lusitana. Parte Terceira, Lisboa: Pedro Craesbeck (reimp. Lisboa: INCM, 2008). [Indiculum fundationis Monasterii Sancti Vicentii (ed.), pp. 291-294. De Expugnatione Scalabis (ed.), pp. 289-191].

Blöcker-Walter, Monica (1966). Alfons I von Portugal. Studien zu Geschichte und Sage des Begrunders der Portugiesichen Unbhangigkeiten. Zürich: Fretz und Wasmuth Verlag. [Annales Domni Alfonsi Regis (ed.), pp. 151-161].

Campa, Mariano de la (2000). «Las versiones alfonsíes de la Estoria de España». In Fernández-Ordóńez (2000), pp. 83-106.

Catalán, Diego (1962). De Alfonso X al Conde de Barcelos. Cuatro estudios sobre el nacimiento de la historiografia romance en Castilla y Portugal. Madrid: Gredos.

— (1995). «La expansión al occidente de la Península Ibérica del modelo historiográfico "Estoria de Espańa" - Nuevas precisiones». In Miscelânea de estudos lingüisticos, filológicos e literários in Memoriam Celso Cunha, Cilene da Cunha Pereira e Paulo Roberto Dias Pereira (orgs.), pp. 521-535. Rio de Janeiro: Nova Fronteira.

- (2000). La épica española. Nueva documentación y nueva evaluación. Madrid: Fundación Ramón Menéndez Pidal.

— (2002). El Cid en la historia y sus inventores. Madrid: Fundación Ramón Menéndez Pidal.

Catalán, Diego e Maria Soledad de Andrés (1970). Edición Crítica del Texto Español de la Cronica de 1344 que Ordenó el Conde de Barcelos don Pedro Alfonso. Madrid: Gredos

Castro, José Ariel de (1992). «Afonso de Portugal, 11 Grão-Mestre da Ordem do Hospital de S. João de Jerusalém, e o Século XII Português». In Actas do Terceiro Congresso da Associação Internacional de Lusitanistas, pp. 819-857. Coimbra.

Cintra, Luís Filipe Lindley (1950a). «O Liber Regum e outras fontes do Livro de Linhagens do Conde D. Pedro». Boletim de Filologia, 11(2), pp. 224-251.

— (1950b). «Uma traduçâo galego-portuguesa desconhecida do Liber Regum». Bulletin Hispanique, 52, pp. 27-40.

— (1951). Crónica Geral de Espanha de 1344, vol. I (Introduçăo). Lisboa: Imprensa Nacional Casa da Moeda.

Cooper, Louis (1960). El Liber Regum. Estudio lingüistico. Zaragoza: Institución «Fernando el Católico». 
David, Pierre (1947). Études historiques sur la Galice et le Portugal du VIe au XIIe siècle. Lisboa: Livraria Portugália Editora.

Falque, Emma (2002). «El llamado Privilegio de los votos, fuente del Chronicon mundi de Lucas de Tuy». Habis, 33, pp. 573-577.

Falque, Emma, Juan Gil e Antonio Maya (1990). Chronica Hispana Saeculi XII (ediderunt). Corpus Christianorum Continuatio Mediaevalis, 71. Turnhout: Brepols. [Chronica Adefonsi Imperatoris (ed.), pp. 149-248].

Fernandes, Hermenegildo (2006). D. Sancho II. Lisboa: Círculo de Leitores.

Fernández-Ordóńez, Inés (1993). Versión crítica de la Estoria de España. Estudio y Edición desde Pelayo hasta Ordoño II. Madrid: Fundación Ramón Menéndez Pidal/Universidad Autónoma de Madrid.

— (2000). Alfonso X el sabio y las crónicas de España (org.). Valladolid: Universidad de Valladolid.

Fernández Valverde, Juan (1987). Roderici Ximenii de Rada de Rebus Hispaniae sive Historia Gothica (cura et studio). Corpus Christianorum Continuatio Mediaevalis, 72. Turnhout: Brepols.

Ferreira, José de Azevedo (1987). Afonso X. Foro Real. 2 voll., Lisboa: INIC.

Ferreira, Maria do Rosário (1998). «Outros Mundos, Outras Fronteiras: Ramiro, Tristão e a divisão da terra de Espanha». In Actas das IV Jornadas Luso-Espanholas de História Medieval - As Relaçôes de Fronteira no Século de Alcañices. Revista da Faculdade de Letras [da Universidade do Porto] - História, II série, 15, pp. 1567-1579.

— (2010). «O Liber Regum e a representação aristocrática da Espanha na obra do conde D. Pedro de Barcelos». e-Spania, 9 [revista on-line]. URL: http://e-spania.revues.org/19675. [Consultado a 2/07/2010].

Guincho, Maria dos Anjos (2001). «A funcionalidade do Relato da Conquista de Santarém na construçấo da imagem de Afonso Henriques». In Actas do $\sigma^{\circ}$ congresso da Associação Internacional de Lusitanistas, Rio de Janeiro: n. pub. [CD-rom].

Herculano, Alexandre (1856). Portugalia Monumenta Historica Scriptores. Lisboa: Academia das Ciências, vol. I [De Expugnatione Scalabis (ed.), pp. 93-95. Carmen Gosuini (ed.), pp. 102-104].

Krus, Luís (1994). Passado, memória e poder na sociedade medieval portuguesa. Redondo: Patrimonia.

- (1998). Lição de Sintese para Provas de Agregação (apresentada à Faculdade de Ciências Sociais e Humanas da Universidade Nova de Lisboa, texto policopiado).

Le Morvan, Gaël (2009). «La Chronica naiarensis: d'un néo-gothisme astur-léonais à un néo-gothisme castillan».e-Spania, 7. URL: http://e-spania.revues.org/index18028.html. [Consultado a 20/11/2009].

Lorenzo, Ramón (1975). La Traduccion Gallega de la Crónica General y de la Crónica de Castilla (ed. crítica anotada, con introducion, índice onomástico y glosário), vol. I. Orense: Instituto de Estudios Orensanos «Padre Feijoó» [ed. texto introdutório (A2a), pp. 900-903; ed. traduçâo galego-portuguesa da Crónica de Castela (A2b), pp. 305-794; ed. epílogo (A2d), pp. 898-900].

Maravall, José Antonio (1997). El concepto de España en la Edad Media (4a ed.). Madrid: Centro de Estudios Constitucionales. 
Martin, Georges (1984). «La chute du royaume visighotique d'Espagne dans l'historiographie chrétienne des VIIIe et IXe siècles». Cahiers de Linguistique Hispanique Médiévale, 9, pp. 207-233.

- (1992). Les Juges de Castille. Mentalités et discours historique dans l'Espagne médiévale. Paris: Klincksieck.

Mattoso, José (1980). Portugaliae Monumenta Historica. Nova Série, vol. II: Livro de Linhagens do Conde D. Pedro. Lisboa: Academia de Ciências de Lisboa.

- (1981). A Nobreza Medieval Portuguesa. A Família e o Poder. Lisboa: Estampa.

- (1982a). «O Mosteiro de Santo Tirso e a Cultura Medieval Portuguesa». In Religião e Cultura da Idade Média Portuguesa, pp. 481-509. Lisboa: Imprensa Nacional Casa da Moeda.

- (1982b). Ricos-Homens, Infançóes e Cavaleiros. A nobreza medieval portuguesa nos séculos XI e XII. Lisboa:

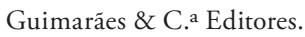

- (1985a) «A crise de 1245». In Portugal Medieval. Novas Interpretações, pp. 57-75. Lisboa: Imprensa Nacional Casa da Moeda.

— (1985b). «A Primeira Tarde Portuguesa». In Portugal Medieval. Novas Interpretaçôes, pp. 11-35. Lisboa: Imprensa Nacional Casa da Moeda.

— (1999). "A transmissão textual dos livros de linhagens». In Lindley Cintra. Homenagen ao Homem, ao Mestre e ao Cidadão, org. Isabel Hub Faria, pp. 565-584. Lisboa: Ediçōes Cosmos.

- (2006). D. Afonso Henriques. Lisboa: Círculo de Leitores.

— (2009a). «A Primeira Crónica Portuguesa». Medievalista on line, 6. URL: http://www2.fcsh.unl.pt/iem/ medievalista/MEDIEVALISTA6/medievalista-mattoso.htm. [Consultado a 15/11/2009].

— (2009b). «O triunfo da monarquia portuguesa: 1258-1264. Ensaio de história política». In Naquele Tempo. Ensaios de história medieval, pp. 515-546. Lisboa: Círculo de Leitores.

Mattoso, José e Joseph Piel (1980). Portugaliae Monumenta Historica. Nova Série, vol. I: Livros Velhos de Linhagens. Lisboa: Academia de Ciências de Lisboa.

Menéndez Pidal, Ramón (1969). La España del Cid, (7a ed.). 2 voll., Madrid: Espasa-Calpe

Miranda, José Carlos Ribeiro (1988). "A “Lenda de Gaia” dos Livros de Linhagens: uma Questão de Literatura?». Revista da Faculdade de Letras [da Universidade do Porto] - Linguas e Literaturas, II série, 5, pp. 483-515.

— (1995). «Os Trovadores e a Região do Porto. I - En Doiro, antr’o Porto e Gaia». O Tripeiro, Junho/Julho, pp. 197-200.

— (1995). «Os Trovadores e a Região do Porto. II - Pois bóas donas som desemparadas». O Tripeiro, Dezembro, pp. 375-381.

— (1998). «A Dimensão Literária da Cultura da Nobreza em Portugal no Século XIII». In Actas das IV Jornadas Luso-Espanholas de História Medieval-As Relaçôes de Fronteira no Século de Alcañices. Revista da Faculdade de Letras [da Universidade do Porto] - História, II série, 15, pp. 1551/1566. 
— (2004). Aurs Mesclatz ab Argen. Sobre a primeira geraçâo de trovadores galego-portugueses. Porto: Edições Guarecer.

— (2009a). "A Introdução à Versão Galego-Portuguesa da Crónica de Castela (A2a): Fontes e estratégias». In Seminário Medieval 2007-2008, M. R. Ferreira, J. C. R. Miranda e A. S. Laranjinha (eds.), pp. 61-97. Porto: Estratégias Criativas. URL: http://www.seminariomedieval.com/guarecer/sm0809/A2aNET\%5Bd efinitivo_11.08\%5D\%5B1\%5D.pdf. [Consultado a 14/09/2009].

— (2009b). «Na génese da Primeira Crónica Portuguesa». Medievalista online, 6. URL: http://www2.fcsh.unl. pt/iem/medievalista/MEDIEVALISTA6/medievalista-miranda.htm. [Consultado a 15/11/2009].

— (2009c). «Do Liber Regum ao Livro Velho de Linhagens». (a publicar em Seminário Medieval 2009). URL: http:// www.seminariomedieval.com/MIRANDA_DO_LR_aoLVL\%5B1\%5D.pdf. [Consultado a 23/12/2009].

- (2010). «Do Liber Regum em Portugal antes de 1340». e-Spania, 9 [revista on-line]. URL: http://e-spania. revues.org/19315. [Consultado a 2/07/2010].

— (no prelo). «Do rex Ranimirus ao Rei Ramiro: A Heráldica Literária em Portugal no séc. XIII» (conferência em curso de publicação nas actas do XIII Congreso de la Asociación Hispánica de Literatura Medieval, Valladolid, 2009).

Miranda, José Carlos Ribeiro e António Resende de Oliveira (1995). «A segunda geração de trovadores galegoportugueses: temas, formas e realidades». In Medioevo y literatura. Actas del V congreso da la Asociación Hispánica de Literatura Medieval, Juan Paredes Núńez (ed.), pp. 499-512. Granada: Universidad de Granada.

Montaner Frutos, Alberto (1988). «La *Gesta de las mocedades de Rodrigo y la Crónica Particular del Cid». In Actas del I Congreso de la Asociación Hispánica de Literatura Medieval, Vicente Beltrán (ed.), pp. 431-444. Barcelona: PPU.

— (2009). «El proyecto historiográfico del Archetypum Naiarense». e-Spania, 7 [revista on-line]. URL: http://espania.revues.org/index18075.html. [Consultado a 20/11/2009].

Moreira, Filipe (2008). Afonso Henriques e a Primeira Crónica Portuguesa. Porto: Estratégias Criativas.

— (2009). «Um novo fragmento da Crónica Portuguesa de Espanha e Portugal de 1341-1342 e suas relaçôes com a historiografia alfonsina». Guarecer on-line (fundo de publicações do Seminário Medieval de Literatura, Pensamento e Sociedade). URL: http://www.seminariomedieval.com/guarecer/fam2009.pdf. [Consultado a 12/10/2009].

- (no prelo). "A primitiva cronística portuguesa e a historiografia castelhana do século XIII: novas hipóteses» (em curso de publicação nas actas do XIII Congreso de la Asociación Hispánica de Literatura Medieval, Valladolid, 2009).

Nascimento, Aires A. (1998). Hagiografia de Santa Cruz. Vida de D. Telo, Vida de D. Teotónio e Vida de Martinho de Soure. Lisboa: Ediçōes Colibri.

- (2001). A Conquista de Lisboa aos Mouros. Relato de um Cruzado. Lisboa: Vega.

Oliveira, António Resende de (1994). Depois do Espectáculo Trovadoresco. A estrutura dos cancioneiros peninsu- 
lares e as recolhas dos sécs. XIII e XIV. Lisboa: Colibri.

— (1995). Trobadores e Xograres. Contexto Histórico. Vigo: Edicións Xerais de Galicia.

— (2001a). «Afinidades Regionais. A casa e o mundo na canção trovadoresca galego-portuguesa». In O Trovador Galego-Português e o seu Mundo, pp. 35-50. Lisboa: Editorial Notícias.

- (2001b). «Arqueologia do Mecenato Trovadoresco em Portugal». In O Trovador Galego-Português e o seu Mundo, pp. 51-62. Lisboa: Editorial Notícias.

Pereira, Maria Teresa Lopes (2000). «Memória cruzadística do feito da tomada de Alacácer (1217)». In Actas do II Congresso Histórico de Guimarães, vol. 2: A política portuguesa e as suas relaçōes exteriores, pp. 321-357. Guimarães: Câmara Municipal de Guimarães.

Pizarro, José Augusto (1999). Linhagens Medievais Portuguesas. Genealogias e Estratégias (1279-1325). 3 voll., Porto: Universidade Moderna.

Ramos, Maria Ana (2004). «Hestorja dell Rej dom Ramjro de lleom... Nova versão de A Lenda de Gaia». Critica del testo, 7(2), pp. 791-843.

Rei, António (2005). «O Livro de Rasis e a memória senhorial da casa dos Aboim-Portel». Callipole, 13, pp. $19-27$.

Ron Fernández, Xabier (2005). «Carolina Michaëlis e os trobadores representados no Cancioneiro da Ajuda». In Carolina Michaëlis e o Cancioneiro da Ajuda hoxe, pp. 121-188. Santiago de Compostela: Xunta de Galicia.

Santos, Herlânder (2009). D. Sancho II. Da deposição à composição das fontes literárias do séc. XIII e XIV (Dissertação de Mestrado apresentada à Faculdade de Letras da Universidade do Porto, policopiada).

Sousa, D. António Caetano de (1739). Provas da História Genealógica da Casa Real Portuguesa. Lisboa: Officina Siliviana da Academia Real (reimp. Coimbra: Atlântida, 1946). [Livro Velho de Linhgens (ed.), pp. 247-267].

Veiga, A. Botelho da Costa (1943). «Os Nossos Nobiliários Medievais (Alguns elementos para a cronologia da sua elaboraçáo)». Lisboa: Separata dos Anais das Bibliotecas e Arquivos.

Ventura, Leontina (1992). A Nobreza de Corte de Afonso III. 2 voll. (Dissertação de Doutoramento apresentada à Faculdade de Letras da Universidade de Coimbra, policopiada).

Vilar, Hermínia Vasconcelos (2005). D. Afonso II. Lisboa: Círculo de Leitores. 